\title{
The Relationship between L1 and L2 Reading Comprehension and Language and Reading Proficiency at the Tertiary Level
}

\author{
Alenka Mikulec \\ University of Zagreb \\ Correspondence concerning this article should be addressed to Alenka Mikulec, Faculty of Teacher \\ Education, University of Zagreb, Trg Republike Hrvatske 14, 10000, Zagreb, Croatia. \\ E-mail: alenka.mikulec@ufzg.hr
}

\author{
Božica Vuić \\ University of Zagreb
}

\begin{abstract}
Correspondence concerning this article should be addressed to Božica Vuić, Faculty of Teacher Education, University of Zagreb, Trg Republike Hrvatske 14, 10000, Zagreb, Croatia.

E-mail: bozica.vuic@ufzg.hr
\end{abstract}

\begin{abstract}
The importance of reading is especially emphasized nowadays when the majority of information, irrespective of the source (books, daily press, professional literature, web sources, etc.), is primarily accessed via reading. Therefore, effective reading and reading comprehension are important in everyday life, but also in an academic setting. This particularly refers to pre-service preschool and primary school teachers, whose teacher training courses imply a good command of reading skills, but also teaching skills required for the development and teaching of prereading and reading skills. In L2 reading, there are additional issues that need to be considered, principally the possibility of skill transfer between the mother tongue and the second/foreign language. Hence, this research aimed to test reading comprehension in both Croatian (L1) and English (L2) languages in a group of university students ( $N=83$ ), studying to become preservice preschool and primary school teachers. Reading comprehension tests and a background questionnaire were used as research instruments in this mixed-method research. Contrary to our expectations, reading comprehension test results were fairly low, i.e. out of a total of 17 points, the mean results for the Croatian language reading comprehension test were $\mathrm{M}=13.6(\mathrm{SD}=2.05)$, while for the English language reading comprehension test they were $\mathrm{M}=11.29(\mathrm{SD}=2.24)$. The results were further correlated with the participants' self-assessed language knowledge and reading abilities in both languages. A positive correlation was found only between the English language reading comprehension test and the participants' self-assessed language knowledge and reading ability. Based on the obtained results, it may be proposed that teachers should focus more on developing reading skills and reading comprehension at all levels as well as in all of the languages that the learners are acquiring, especially in view of the proposed possibility of the transfer of skills among languages.
\end{abstract}

Keywords: language knowledge; reading; reading comprehension; self-assessed reading proficiency; transfer of skills

\section{Introduction}

\section{Reading and Comprehension}

It is difficult to imagine life in the modern world without reading because most of the information needed for everyday life is received (and transmitted) in written form. Therefore, it may be proposed that "A society can exist - many do exist - without writing, but no society can exist without reading” (Manguel, 1996, p. 7). 
In addition to being conditio sine qua non of living in complex contemporary circumstances, reading has been attracting the interest of many scholars from different disciplines. Such an interdisciplinary approach to this phenomenon has yielded numerous definitions, thus confirming its complexity as there is still no single nor unambiguous denotation of the two main concepts: reading and reading comprehension. The development of reading as a skill followed by the development of reading ability (Pavličević-Franić, 2005) have been marked as a basic prerequisite of reading and comprehension. In reading models and theories, reading has been emphasized as an active or interactive process (Carrell, 1983; Grabe, 1988; Šamo, 2014) ${ }^{1}$, which, in addition to the context of reading and the framework of individual readers' possibilities, includes both top-down and bottom-up models of interaction and text processing. Fostering the development of pre-reading skills generally starts in early childhood, and is particularly intense in the pre-primary stage, when reading as a language skill is associated with the other three language skills, i.e. listening, speaking, and writing. However, structured reading (and writing) instruction in Croatia does not begin until children start the first grade of primary school (Bežen, 2008; Teaching Plan and Programme for Primary School, 2006). In order for reading to transition from a skill to a person's ability level, reading comprehension as one of the key objectives of this language skill needs to be developed (Čudina-Obradović, 2014). Hence, during the stimulation and development of pre-reading and reading skills through various (non)structured activities and initial reading and writing instruction, preschool and primary school teachers need to constantly ask questions about both denotative and connotative meaning of words. In addition, by using various educational games, teachers may implement lexical-semantic exercises in accordance with cognitive and experiential abilities of early and preschool-aged, as well as primary school children. Thus, from the very beginning, the basic principle of reading is affirmed, stating that whatever one is reading, the focus should be on comprehension. Moreover, by revealing and comprehending different semantic layers in the information obtained through reading, we not only find the cognitive messages, but we also perceive the beauty in these messages, which is important both for the emotional and aesthetic development of preschool and early school-aged children. While reading, it is important to focus attention on the content, that is, the message that can be comprehended on the cognitive and emotional level, thus facilitating the discovery of the meaning of the entire text. According to Čudina-Obradović (2014, p. 193), the "complex idea of the text as a whole" is formed on the basis of previously acquired processes - from word meaning recognition to sentence meaning recognition and its implications (finding the propositions), and to making conclusions about how propositions are connected into a complex network of meanings for the purpose of building a mental model that would facilitate the deciphering of different semantic, linguistic, ethical, aesthetic and other text layers, especially in a literary text. In addition, reading comprehension facilitates the use of knowledge and its possible modifications, simultaneously revealing the world within and around each person at multiple levels. Among the preconditions for effective reading comprehension, a number of factors also need to be considered. Two important factors are language proficiency and reading skills, on which data may be obtained through tests or self-assessment. Although any data that is obtained through self-report heavily relies on the learners' honesty, the Common European Framework of Reference (Vijeće Europe, 2005) states that self-assessment may be used as a support measure, especially when a student's future does not directly depend on the assessment results.

\section{The Transfer of Skills between L1 and L2}

Reading and comprehension in an L1, as described in the previous section, are still considered less complex when compared to reading and comprehension in an L2. Despite the apparent differences between the L1 and L2, it has frequently been emphasized that the development of second/foreign language skills and knowledge is closely connected to the skills already existing in one's mother tongue (Gottardo \& Mueller, 2009; Sparks, Patton, Ganschow, \& Humbach, 2009). In addition, research has confirmed the existence of interlingual interactions and transfer between L1 and L2 (Mihaljević Djigunović, 2006; Sparks, Patton, \& Luebbers, 2019), and the interaction has also been found to be bi-directional (Brown \& Gullberg, 2008; Pavlenko \& Jarvis, 2002). In other words, multilinguals' competences may best be described if viewed holistically as a global system with dynamically interacting subsystems (Cook, 1992; Herdina \& Jessner, 2002), where the two (or more) languages are constantly interacting, thus contributing to either positive or negative transfer between the languages (see Koda (2004) for an overview of language transfer research).

Grabe (2010) asserts that L2 readers tend to transfer inherent cognitive reading skills such as phonological

\footnotetext{
1 Hudson, T. (2007). Teaching second language reading. Oxford, UK: Oxford University Press; Grellet, F. (1981). Developing reading skills: A practical guide to reading comprehension exercises. Cambridge, UK: Cambridge University Press.
} 
and orthographic processing from one language to the other. Cross-language transfer of cognitive-linguistic abilities was also confirmed in a study investigating whether early reading abilities in an L1 may predict later literacy development in an L2 (Shum, Ho, Segel, \& Au, 2016). A number of studies (Pae, 2018; Proctor, August, Carlo, \& Snow, 2006; van Gelderen, Schoonen, Stoel, de Glopper, \& Hulstijn, 2007; Yamashita, 2001) have confirmed significant relationships between L1 and L2 reading comprehension. Moreover, some studies have also confirmed that the mentioned influence may be bi-directional, i.e. L2 reading skills and strategies may influence L1 reading (Schwartz, Mendoza, \& Meyer, 2017; Spies, Lara-Alecio, Tong, Irby, Garza, \& Huerta, 2018). However, despite the possibility of the transfer, Grabe (2010) warns that it does not occur automatically, nor is it always positive, as there are a number of factors that may affect this process, whereby the two most frequently considered factors are reading ability and language proficiency in both the L1 and L2.

\section{Aim and Hypotheses}

The aim of the research was twofold: 1) to test reading comprehension (RC) in the Croatian and English languages on a sample of university students, and 2) to determine whether there is correlation between reading comprehension test results and students' self-assessed language proficiency and reading abilities in both languages.

Based on these objectives, the following hypotheses have been proposed:

H1. RC test results in the participants' mother tongue (Croatian) will be higher than those in the foreign language (English).

H2. A positive correlation will be established between RC test results in Croatian and English.

H3. A positive correlation will be determined for the Croatian RC test results, and the participants' self-assessed language proficiency and reading abilities in Croatian.

H4. A positive correlation will be determined for the English RC test results and the participants' self-assessed language proficiency and reading abilities in English.

\section{Materials and Methods}

\section{Participants}

A convenience sample of $\mathrm{N}=83$ female university students, whose average age was $\mathrm{M}=21.34(\mathrm{SD}=1.61)^{2}$, participated in the research. The participants were enrolled in a two-semester English for Academic Purposes course at primary and preschool teacher education study programmes in Zagreb and Petrinja (Croatia). During their teacher education studies, students in Croatia enrol in a number of language and teaching methodology courses, where they acquire and develop knowledge about different reading strategies, and learn how to implement structured reading activities, teach reading, and assess reading comprehension. The reason this particular group of students was chosen for the research is because they will have to demonstrate a good command of reading comprehension and use different reading strategies in their future profession.

\section{Materials}

A mixed-method research design was applied in the study, i.e. the obtained results were analysed both qualitatively and quantitatively. The following research instruments were used: 1) a background questionnaire, which yielded data on the participants' age, language learning history, and a self-assessment of their language skills and reading abilities, and 2) reading comprehension tests in Croatian and English, specially designed for the present research. The tests comprise expository texts because this text type is most often used in academic writing (Benson, 1991). Both texts were taken from a developmental psychology university textbook (Vasta, Haith, \& Miller, 1998), since Developmental Psychology is one of the courses taken by the research participants in both study programmes. According to Litz and Smith (2006), it is important, especially in testing, to use texts dealing with topics about which students possess appropriate knowledge (schemas) because in this way the application of logical thinking and conclusion skills is facilitated during text comprehension and processing. In the end, since it is considered that task type can contribute to students' success or failure on the test (Ferbežar

\footnotetext{
${ }^{2}$ The research described in this paper is part of a larger study conducted in the process of the first author's PhD thesis writing, which investigated reading comprehension and reading strategies used by a group of university students in Croatia.
} 
\& Požgaj-Hadži, 2008), during test construction, participants' preferences have been considered, and various types of assignments and testing techniques were included. Each of the two tests consists of five tasks - two objective task types and three semi-open or open-ended tasks since this type of task is considered to positively influence deeper processing when reading (Carrell, Pharis, \& Liberto, 1989). The task types are: 1) a gapped text with four sentences removed, the participants' task being to complete the text by correctly inserting the missing sentences, 2) open-ended question(s) related to the ideas presented in the text, 3) true/false statements based on the information given in the text, 4) suggesting an appropriate title for the given text, and 5) summarizing the text in $2-3$ sentences.

\section{Procedure}

The sample of participants was a convenience one and included students enrolled in an English for Academic Purposes (EAP) course at the higher education institution where the two researchers are employed. Prior to the research, all the participants were informed that their participation would be anonymous and voluntary and they could leave at any time. The purpose of the research was explained and they were asked to sign a consent form. The research itself was conducted in two phases, with the first phase including the completion of a penand-paper background questionnaire and the reading comprehension test in English. During the second phase two weeks later, the students completed the reading comprehension test in their L1 (Croatian). The research was conducted during regular EAP classes, and students were assured that the results would not affect their grades in the abovementioned course.

Given that the assessment of open-ended tasks has been criticized for its potential for subjectivity, evaluation scales were prepared for these tasks (tasks 4 and 5) in both RC tests, and three independent assessors evaluated the participants' responses in both languages. Finally, it is important to note that the participants had access to the texts while solving the tasks because the researchers wanted to eliminate any potential problems with information retrieval, which is often one of the factors contributing to students' success or failure when solving open-ended tasks (Alderson, 2000, p. 6).

\section{Data Analysis}

The obtained quantitative data were processed using the statistical package SPSS 15.0 for Windows (Statistical Package for Social Sciences), and the methods applied were those of descriptive statistics (frequencies, arithmetic mean (M), and standard deviation (SD)), inferential statistics (t-test), and correlation analyses.

\section{Results and Discussion}

\section{Reading comprehension test in Croatian as the $\mathrm{L1}$}

The reading comprehension (RC) test was written in Croatian, and the participants were instructed to write their answers in Croatian as well. The obtained mean out of 17 possible points on the RC test in Croatian was M $=13.60(\mathrm{SD}=2.05)$, with a minimum score of 6 and a maximum of 17 . The first task on the test was an objective task in which the participants were asked to complete the text with the four omitted sentences listed below the text. According to established practice (Ferbežar \& Požgaj-Hadži, 2008), in this type of task students receive 1 point for each correct sentence. The mean score was $3.31(\mathrm{SD}=1.09)$, i.e. the majority of participants $(\mathrm{N}=58$, $69.9 \%$ ) achieved the maximum number of points (Table 1 ). The majority of mistakes (15.66\%) were related to the inverted order of the second and third omitted sentences. Although there are clear signals in the text that facilitate task solving (the phrase in the text is '...the only difference being that here the emphasis is on learning the general ways of approaching others...', and the omitted sentence is 'Such ways of approaching can be sharing a toy....'), some research participants failed to identify them, and the reason may be a lack of focus when reading.

For the second task, the participants were required to find specific information in the text and write it down. According to the assessment criteria, for each correct piece of information, the participants were given 0.5 of a point. The analysis of the results shows a relatively good score $(\mathrm{M}=2.15, \mathrm{SD}=0.67)$, i.e. the highest percentage of participants $(\mathrm{N}=33,39.8 \%)$ received 2.5 out of the total of 3 points, and $15.7 \%(\mathrm{~N}=13)$ had the maximum 
number of points (Table 1). Although most answers were at least partially paraphrased, and since the instructions did not specify that copying verbatim was forbidden, such answers were also accepted as correct. The most common phrases copied verbatim belong to professional jargon: 'unpopular child', 'intervention programme(s)', 'socially competent children', 'social skills', etc.

The third task was true/false, which, according to Alderson (2000), is a popular testing technique, primarily because of the ease of its preparation. However, the author also states that the problem with this technique is that, because two responses are provided (correct/incorrect), the students have a fifty-fifty chance of guessing the correct answer. This may also have been the case in this research since this was the best-solved task on the whole test $(\mathrm{M}=3.86, \mathrm{SD}=0.34)$, with $86.7 \%(\mathrm{~N}=72)$ of the participants achieving the maximum number of points (Table 1).

Table 1

Croatian language reading comprehension test scores according to tasks

\begin{tabular}{|c|c|c|c|c|c|c|c|c|c|c|}
\hline \multirow[b]{2}{*}{$\begin{array}{l}\text { Number } \\
\text { of points }\end{array}$} & \multicolumn{2}{|c|}{$\begin{array}{c}1 \text { st task } \\
(\max =4 \text { points }) \\
(\mathrm{M}=3.31 ; \mathrm{SD}=1.09)\end{array}$} & \multicolumn{2}{|c|}{$\begin{array}{c}\text { 2nd task } \\
\text { (max.= } 3 \text { points }) \\
(\mathrm{M}=2.15 ; \\
\mathrm{SD}=0.67)\end{array}$} & \multicolumn{2}{|c|}{$\begin{array}{c}\text { 3rd task } \\
\text { (max.=4 points) } \\
(\mathrm{M}=3.86 ; \\
\mathrm{SD}=0.34)\end{array}$} & \multicolumn{2}{|c|}{$\begin{array}{c}\text { 4th task } \\
\text { (max.= } 3 \text { points) } \\
(M=1.62 ; \\
S D=0.56)\end{array}$} & \multicolumn{2}{|c|}{$\begin{array}{c}\text { 5th task } \\
\text { (max.=4 points) } \\
(\mathrm{M}=2.61 ; \\
\mathrm{SD}=0.75)\end{array}$} \\
\hline & $\mathbf{f}$ & $\%$ & f & $\%$ & f & $\%$ & f & $\%$ & f & $\%$ \\
\hline 0 & 1 & 1.2 & 1 & 1.2 & 0 & 0 & 0 & 0 & 0 & 0 \\
\hline 0.5 & & & 2 & 2.4 & & & 1 & 1.2 & 0 & 0 \\
\hline 1 & 5 & 6 & 7 & 8.4 & 0 & 0 & 23 & 27.7 & 3 & 3.6 \\
\hline 1.5 & & & 9 & 10.8 & & & 30 & 36.1 & 9 & 10.8 \\
\hline 2 & 19 & 22.9 & 18 & 21.7 & 0 & 0 & 15 & 18.1 & 14 & 16.9 \\
\hline 2.5 & & & 33 & 39.8 & & & 12 & 14.5 & 20 & 24.1 \\
\hline 3 & 0 & 0 & 13 & 15.7 & 11 & 13.3 & 2 & 2.4 & 18 & 21.7 \\
\hline 3.5 & & & & & & & & & 15 & 18.1 \\
\hline 4 & 58 & 69.9 & & & 72 & 86.7 & & & 4 & 4.8 \\
\hline
\end{tabular}

For the fourth task, the participants were asked to propose a title that would best fit the text they had read. Visinko (2014) states that this is one of the ways in which summarizing strategies can be taught and practiced. Research results obtained by Šamo (2011) have shown a significant correlation between the ability to interpret a text that was being read and summarizing its main points into a title, which confirms the appropriateness of this technique for testing reading comprehension. Since this is an open-type task, the criteria for the evaluation of participants' responses were defined according to the ones proposed by Rončević Zubković (2008). The task was assessed by three evaluators, and points were awarded with respect to the extent to which the title corresponded with the content, its linguistic accuracy, and whether or not it was copied verbatim from the text. The average score on this task was relatively low $(\mathrm{M}=1.62, \mathrm{SD}=0.56)$. Most participants $(\mathrm{N}=31,36.1 \%)$ achieved 1.5 out of 3 points, and the maximum number of points was only scored by two participants. The original title of the article is Peers as Therapists, and the participants' responses showed that most of them recognized, at least partially, the underlying problem discussed in the text. Some of the proposed titles similar to the original were as follows: 'Peers as Therapists in Intervention Programmes', 'A Small Child - A Great Therapist', 'Peers Therapists', and 'Peers as Social Therapists'. The titles that were not identical to the original, but corresponded to the topic of the text were also accepted as correct: 'Intervention Programmes for Children', 'Helping Children Who Are Unpopular among Peers', 'Helping Children Improve Their Social Skills', 'Enhancing Social Skills with the Help of Peers', and 'Using Interventions to Improve Children's Social Skills'. Some of the answers indicated participants' recognition of the basic theme or part of it, but they were either too general: 'Behaviour Patterns and Problems among Peers', 'Teaching Methods Useful with Children', and 'Unpopular Child and His/Her Peers', 'Children's Social Skills'; inaccurate: 'Intervention Programmes According to Odom and Strain in Which Peers Participate'; or unfinished: 'How to Include Less Socially Competent Children?'. Language errors were minimal and, since the phrases written by the participants were relatively short, no relationship between proficiency level in the Croatian language and the provided answers was observed. 
For the fifth task, the participants were required to summarize the text. Summarizing "implies recognition, paraphrase and integration of essential information from the text" (Kolić-Vehovec \& Muranović, 2004, p. 97), in other words, separating the relevant from the irrelevant information and organization of the selected data (Šamo, 2011), which is why it is considered one of "the most effective reading and learning strategies" (Pečjak et al., 2009, p. 258). Summary writing has been selected for this test because it is generally applied after reading (Duffy, 2009) and when practicing the retelling of a text (Visinko, 2014). Moreover, since the successful understanding of a text is essential for identifying key information (Celce-Murcia \& Ohlstain, 2000), summarizing can be used as a good indicator of text comprehension. Evaluation criteria for this task have partially been defined according to Kolić-Vehovec and Muranović (2004): expressing the main idea, staying within the given frame with respect to the length, and using one's own words in writing the summary. The criteria that have been added are the language acceptability and the cohesion and coherence of the text. The obtained average result was relatively low $(\mathrm{M}=2.61, \mathrm{SD}=0.75)$, and the most common reason seems to be the participants' failure to recognize the most important information, or the fact that the proposed summary was either too long or too short. Other mistakes that were observed were a lack of coherence and cohesion in the summary, inappropriate style, wrong collocations, as well as adding information related to personal experiences rather than summarizing the information presented in the text (e.g. 'Peers are the reason why some children are unpopular', 'There are unpopular children in each class. The goal of the preschool teacher is to integrate them with the other children').

\section{Reading comprehension test in English as L2}

This reading comprehension (RC) test was written in English, and the participants were required to write their answers in English as well, except for the last task - summarizing. Participants were given clear instructions that the abstract should be written in their mother tongue because the objective of the task was not to test the participants' production in their L2, but rather their comprehension. In other words, writing a summary in a foreign language may constitute a problem for L2 users since, despite text comprehension, they may not be able to express their ideas in the L2 due to insufficient language skills (Alderson, 2000). The obtained average score on the RC test in English was $\mathrm{M}=11.29$ ( $\mathrm{SD}=2.45$ ), out of a total of 17 points, with the minimum score being 5 points and the maximum 16 points. One possible reason for the participants' relatively poor results on the test could be their insufficient vocabulary knowledge, which has been found to be one of the best predictors of reading comprehension (Burgoyne, Whiteley, \& Hutchinson, 2011; Pečjak, Kolić-Vehovec, Rončević Zubković, \& Ajdišek, 2009). Nagy and Scott (2000, as cited in Pečjak et al., 2009) argued that the knowledge and understanding of 9095\% of words in the text is necessary for comprehension. In addition, readers' background knowledge (Visinko, 2014) is also important, and it is possible that for some participants in the present research this knowledge may have been insufficient.

Table 2

English language reading comprehension test scores according to the tasks

\begin{tabular}{|c|c|c|c|c|c|c|c|c|c|c|}
\hline \multirow[b]{2}{*}{$\begin{array}{l}\text { Number } \\
\text { of points }\end{array}$} & \multicolumn{2}{|c|}{$\begin{array}{c}\text { 1st task } \\
(\max .=4 \text { points }) \\
(M=2.33 ; \\
S D=1.11)\end{array}$} & \multicolumn{2}{|c|}{$\begin{array}{c}\text { 2nd task } \\
\text { (max. }=3 \text { points) } \\
(\mathrm{M}=1.55 ; \\
\mathrm{SD}=0.76)\end{array}$} & \multicolumn{2}{|c|}{$\begin{array}{c}\text { 3rd task } \\
(\mathrm{max} .=4 \text { points }) \\
(\mathrm{M}=3.46 ; \\
\mathrm{SD}=0.70)\end{array}$} & \multicolumn{2}{|c|}{$\begin{array}{c}\text { 4th task } \\
(\max .=3 \text { points }) \\
(\mathrm{M}=1.72 ; \mathrm{SD}=0.58)\end{array}$} & \multicolumn{2}{|c|}{$\begin{array}{c}\text { 5th task } \\
\text { (max. }=4 \text { points) } \\
(M=2.20 ; \\
S D=0.67)\end{array}$} \\
\hline & $\mathbf{f}$ & $\%$ & f & $\%$ & f & $\%$ & $\mathbf{f}$ & $\%$ & f & $\%$ \\
\hline 0 & 1 & 1.2 & 3 & 3.6 & 0 & 0 & 2 & 2.4 & 1 & 1.2 \\
\hline 0.5 & & & 5 & 6 & & & 1 & 1.2 & 2 & 2.4 \\
\hline 1 & 16 & 19.3 & 26 & 31.3 & 2 & 2.4 & 13 & 15.7 & 2 & 2.4 \\
\hline 1.5 & & & 19 & 22.9 & & & 28 & 33.7 & 14 & 16.9 \\
\hline 2 & 43 & 51.8 & 15 & 18.1 & 4 & 4.8 & 21 & 25.3 & 23 & 27.7 \\
\hline 2.5 & & & 6 & 7.2 & & & 18 & 21.7 & 24 & 28.9 \\
\hline 3 & 0 & 0 & 9 & 10.8 & 31 & 37.3 & 0 & 0 & 14 & 16.9 \\
\hline 3.5 & & & & & & & & & 3 & 3.6 \\
\hline 4 & 23 & 27.7 & & & 46 & 55.4 & & & 0 & 0 \\
\hline
\end{tabular}


For the first task, just as on the RC test in Croatian, the participants were asked to complete the text with the four omitted sentences listed below the text. The average score was $2.33(\mathrm{SD}=1.11)$, which means that more than half of the participants ( $\mathrm{N}=43,51.8 \%$ ) scored at least 2 out of a total of 4 points. The results also show that only $27.7 \%(\mathrm{~N}=23)$ of the participants achieved the maximum number of points on this task (Table 2). However, it is interesting that as many as $45.78 \%(\mathrm{~N}=38)$ of the participants inverted the order of the third and the fourth omitted sentences. The reason may be because the third sentence begins with the connective 'finally', and the participants may have mistakenly inserted it as the last in the text. This might indicate insufficient knowledge of connectives, which, in addition to metacognitive knowledge, have been found to be important for expository text comprehension (Welie, Schoonen, Kuiken, \& van den Bergh, 2017).

For the second task, the participants had to find specific information in the text and use it to answer questions. For each correct answer, they received 0.5 of a point. The analysis of participants' scores indicated relatively poor results $(\mathrm{M}=1.55, \mathrm{SD}=0.76)$, especially since $31.3 \%(\mathrm{~N}=26)$ of the participants achieved only 1 out of 3 points, while only $10.8 \%(\mathrm{~N}=9)$ of the participants received all 3 points (Table 2$)$. This may be because they failed to identify the required information. Further analysis of the participants' answers revealed that most of them partially $(\mathrm{N}=59,71 \%)$, or completely $(\mathrm{N}=13,15.6 \%)$ copied phrases from the text, that is, only a few of the participants $(\mathrm{N}=9,10.8 \%)$ used paraphrasing. Such answers, as in the RC test in Croatian, were accepted as correct because task instructions did not specify that verbatim copying of the phrases from the text was forbidden, and the purpose of the task was not to test the participants' use of the English language but their reading comprehension. However, such a high percentage of complete or partial verbatim copying may pose a reason for concern. A possible explanation may be that because of their subjective or objective feeling of insufficient language competence in their L2, participants felt safer using the phrases from the original text, as was found in another research (Wu, 2013). Another reason may be their insufficiently developed and/or previously acquired (wrong) reading and/ or learning strategies. Namely, the results of the PISA 2009 survey (Braš Roth, Markočić Dekanić, Markuš, \& Gregurović, 2010, p. 142) showed that as many as $49.32 \%$ of unsuccessful secondary school students in Croatia considered verbatim copying of sentences from a text to be a successful strategy. Naturally, additional tests and analyses should be carried out before making any definite conclusions about the causes of such language behaviour.

The analysis of the participants' paraphrased responses showed that paraphrase was used almost equally by participants with higher and lower levels of language proficiency ${ }^{3}$. However, in the answers provided by participants with a lower level of language proficiency more language errors were identified although the answers clearly indicated that they understood the text: S8 (self-assessment 3):...' 'they can avoid contact with the person who punish"*4 he/ she*'; S9 (self-assessment 2): 'children who exposed* to physical punishment may become aggresive* parent" latter*'. Conversely, and in line with the expectations, the participants with a higher level of language proficiency made fewer and minor language errors: S32 (self-assessment 4): 'if we use it appropriate*', or none at all, and a satisfactory level of reading comprehension and language use is apparent: S22 (self-assessment 5): 'punishment can reduce behaviours that are not a problem'; S36 (self-assessment 4): 'the punisher becomes the object of hate'; S51 (self-assessment 5): 'it can eliminate behaviour that was not a problem'. The paraphrased answers contained mostly minimal interventions such as omitting (in)definite articles or changing word classes (e.g. 'avoiding' instead of 'avoid', 'reduce' or 'reduction' instead of reducing, 'aggressive' instead of 'aggression'). The analysis confirmed that the proficiency level was again a significant factor, as the less proficient participants showed a considerable lack of comprehension: S11 (self-assessment 3): 'punishment is not a good teaching*', S31 (self-assessment 3): 'the individual who delivers the punishment sometimes becomes so closely associated"', S83 (self-assessment 3): 'Published" behaviour will not occur again'. In the last example, it is not completely clear whether the use of the word 'published' instead of 'punished' was merely a 'slip of the tongue', or whether the participant, because of insufficient language knowledge, replaced an unknown word with another that is phonologically similar to the original.

The third task was true/false, which, as mentioned earlier, may not be the most reliable as the participants may resort to guessing the correct answer. There is a possibility that this was the case in the present research since it was the best-solved task on the whole test $(\mathrm{M}=3.46, \mathrm{SD}=0.70)$, that is $55.4 \%(\mathrm{~N}=46)$ of the participants

\footnotetext{
3 Participants' language proficiency was determined on the basis of their self-assessment, and is expressed on a scale 1-5, where 1 indicates insufficient and 5 excellent language knowledge.

4 All examples provided here are quotes of the students' answers and * signals words or phrases which have been written or used incorrectly by the students.
} 
achieved the maximum number of points (Table 2). The analysis of the results showed that $37.3 \%(\mathrm{~N}=31)$ of the participants made a mistake on the first sentence in the task ('Mild punishment can be effective in reducing undesirable behaviours'). It is assumed that the error is merely a result of the participants' haste and lack of attention, rather than lack of reading and / or language skills because the text that refers to this task states: 'Indeed, moderate to strong punishment, if delivered clearly and consistently, is effective in reducing undesirable behaviours. Mild punishment, in contrast, can actually increase the behaviour...'.

The fourth task required the participants to propose the most appropriate title for the given text, and just as the task on the Croatian RC test, the criteria were defined in advance, and the tasks were scored by three independent scorers. The results show that the average score on this task was relatively low $(\mathrm{M}=1.72, \mathrm{SD}=0.58)$. The highest percentage $(\mathrm{N}=28,33.7 \%)$ of the participants received 1.5 out of 3 points, while no one scored the maximum number of points (Table 2). The original title of the text is Effects and Side Effects of Punishment by Parents or Teachers, and the analysis of the responses indicates that the vast majority $(\mathrm{N}=25,30.12 \%)$ corresponded to the original: 'Advantages and Disadvantages of Punishment', '(Dis)advantages of Punishment', and 'Good and Bad Sides of Punishment'. Šamo (2011) also found that on this type of assignment students most often use the words from the text, which, in addition to some of the previously mentioned reasons, may also be interpreted as an insufficiently developed ability to independently review the text. However, the reason why most of the titles proposed by the participants in this research contain the words 'advantages' and 'disadvantages' may be because the participants were asked to list advantages and disadvantages of punishment on the second task. Furthermore, most answers did identify punishment as a basic idea although some of the participants used inaccurate language or the answers were incomplete: S33 'What is Punishment?', S32 'Use* Punishment or Not?', S44 'Punishment - Is It Really the Best Choice?', S46 'Punishment is Not Always the Best Choice', S48 'Punishment and Its Consequences', S50 ‘Should We Punish Our Children?', and S53 'Punishment - To Be or Not to Be'. In some of the answers, punishment was recognized as the basic idea, but its interpretation was incorrect: S2 'Facts about Punishment', S58 'Punishment Destroyed Child* Soul', and S73 'Reduce Your Punishment'. Some of the titles were too detailed, which may be an indication of insufficiently developed summarizing skills. Further analysis and a comparison of the answers with the participants' language proficiency confirmed a relationship. Namely, participants with higher proficiency provided answers which were not only more accurate but also showed ingenuity and creativity: S70 (self-assessment 5): 'Punishment - How It Reflects on Children', S72 (self-assessment 5): 'Advantages and Disadvantages of Using Punishment as a Parenting Technique', S80 (selfassessment 4): 'Punishment and Behaviors: What's and Why's', and S23 (self-assessment 4): '(Dis) Advantages of Punishment'. As expected, answers provided by less proficient participants had more language errors: S52 (self-assessment 3): 'Punishment Is Not an* Answear"', S76 (self-assessment 2): 'Punishment in the Fifth" Facts', S10 (self-assessment 3): 'The Propriate* Punishment for the* Children', S11 (self-assessment 3): 'Do Not Punishment*, Teach Them!', and S12 (self-assessment 2): 'Punishment for a* Children's*'.

For the fifth task, the participants were required to write the text summary, thus demonstrating their comprehension and the ability to synthesize the information presented in the text. In scoring the tests, the three evaluators used the same criteria as for the test in Croatian. The analysis showed that a relatively low average score $\mathrm{M}=2.20$ ( $\mathrm{SD}=0.67$ ) was achieved, with the highest percentage of participants achieving $2(\mathrm{~N}$ $=23,27.7 \%)$ or 2.5 points $(\mathrm{N}=24,28.9 \%)$ out of a total of 4 . The most frequent mistakes resulted from the participants' inability to identify the most important facts. This may be related to the results of the PISA 2009 survey, which showed that checking whether the most important facts have been identified for summary writing was considered effective by all of the most successful Croatian secondary school students as opposed to the unsuccessful ones, of whom only $51.41 \%$ considered this strategy to be effective (Braš Roth et al., 2010, p. 142). Additionally, a common mistake observed in the present study was related to the fact that the summaries significantly exceeded the prescribed length. This further confirms the observation that Croatian students do not have sufficiently developed skills for separating important from less important information. One possible explanation for the obtained results may also be the participants' over-reliance on text features through the bottom-up model, i.e. it was found that because of the complexity of the language, students may have been unable to identify the key idea (Carrell, 1988; Celce-Murcia \& Olshtain, 2000).

Thus, it can be concluded that, given the presented results, it would be advisable to include in the curriculum some form of teaching summarizing and other reading strategies, especially as research has shown that reading strategy instruction may result in significant progress in reading (Kolić-Vehovec \& Muranović, 2004; Okkinga, van Steensel, van Gelderen, van Schooten, Sleegers, \& Arends, 2018; Vaughn, Swanson, Roberts, Wanzek, 
Stillman-Spisak, Solis, \& Simmons, 2013), and it has also been related to student attitudes toward reading and the motivation to read (Huang \& Chen, 2019).

\section{Comparison of the reading comprehension test results and the participants' self-assessed language proficiency and reading skills}

By comparing the mean values of the total results from the reading comprehension tests in Croatian and English, a statistically significant difference $(t=8.605, \mathrm{df}=82, \mathrm{p}=0.000)$ was determined in favour of the RC test in Croatian. The analysis of individual tasks using the $\mathrm{t}$-test showed that, apart from the fourth task (summarizing the text into a corresponding title), higher values were obtained on the RC test in Croatian, which confirms the first hypothesis.

Table 3

T-test for reading comprehension test results in L1 and L2 by task (Mikulec, 2016, p. 140)

\begin{tabular}{|c|c|c|c|c|c|c|c|}
\hline & prehension (RC) test & $\mathbf{N}$ & $\mathbf{M}$ & SD & $\mathbf{t}$ & df & $\mathbf{p}$ \\
\hline \multirow{2}{*}{$1^{\text {st }}$ task } & $\mathrm{RC}$ test in Croatian & 83 & 3.31 & 1.09 & \multirow{2}{*}{6.531} & \multirow{2}{*}{82} & \multirow{2}{*}{0.000} \\
\hline & RC test in English & 83 & 2.34 & 1.12 & & & \\
\hline \multirow{2}{*}{$2^{\text {nd }}$ task } & $\mathrm{RC}$ test in Croatian & 83 & 2.16 & 0.67 & \multirow{2}{*}{6.318} & \multirow{2}{*}{82} & \multirow{2}{*}{0.000} \\
\hline & RC test in English & 83 & 1.55 & 0.77 & & & \\
\hline \multirow{2}{*}{$3^{\text {rd }}$ task } & RC test in Croatian & 83 & 3.87 & 0.34 & \multirow{2}{*}{5.091} & \multirow{2}{*}{82} & \multirow{2}{*}{0.000} \\
\hline & RC test in English & 83 & 3.46 & 0.70 & & & \\
\hline \multirow{2}{*}{$4^{\text {th }}$ task } & $\mathrm{RC}$ test in Croatian & 83 & 1.62 & 0.56 & \multirow{2}{*}{-1.106} & \multirow{2}{*}{82} & \multirow{2}{*}{0.272} \\
\hline & RC test in English & 83 & 1.72 & 0.59 & & & \\
\hline \multirow{2}{*}{$5^{\text {th }}$ task } & $\mathrm{RC}$ test in Croatian & 83 & 2.61 & 0.75 & \multirow{2}{*}{4.161} & \multirow{2}{*}{82} & \multirow{2}{*}{0.000} \\
\hline & RC test in English & 83 & 2.20 & 0.68 & & & \\
\hline
\end{tabular}

The data on the participants' self-assessed Croatian and English language proficiency and their reading skills in both languages were collected with the background questionnaire. T-test was used to compare participants' self-assessment of English as a foreign language (L2) $(\mathrm{M}=3.64)$ and Croatian as a mother tongue (L1) $(\mathrm{M}=4.23)$, and a statistically significant difference $(t=-5.737, \mathrm{df}=82, \mathrm{p}=0.000)$ in favour of the L1 was found. It can be concluded that, as expected since Croatian is their mother tongue, the participants assessed their L1 proficiency to be higher than their L2 proficiency.

The results of the participants' self-assessed reading skills were similar to those of their self-assessed L1 and L2 skills. In other words, the average grade for the participants' self-assessed reading skills in English was $\mathrm{M}=$ $3.49(\mathrm{SD}=0.80)$, while for Croatian it was somewhat higher at $\mathrm{M}=4.66(\mathrm{SD}=0.50)$. The t-test again confirmed a statistically significant difference $(t=13.164, \mathrm{df}=82, \mathrm{p}=0.000)$ in favour of the mother tongue.

In the research conducted by Perkins, Brutten, and Pohlman (1989, as cited in Grabe, 2009), a statistically significant positive correlation was found between L2 proficiency and L2 reading comprehension, as well as a low correlation between L1 and L2 reading comprehension. Correlation analysis of the examined variables was also applied in this study and the obtained results were similar to those mentioned above. In other words, the analysis of the RC test results in the L1 and L2 showed a statistically significant positive correlation $(\mathrm{r}=0.424$, $\mathrm{p}=0.000$ ), thus confirming the second hypothesis, and indicating a possible transfer of skills between the two languages, as proposed by other researchers (Cook, 2003; Koda, 2004; Mihaljević Djigunović, 2006).

A positive correlation was also determined between L1 reading comprehension test results and L2 language proficiency $(r=0.251, p=0.000)$ and self-assessed reading abilities in the $\mathrm{L} 2(\mathrm{r}=0.254, \mathrm{p}=0.021)$. However, no positive correlation was established between the L1 reading comprehension test and L1 self-assessed proficiency, nor with self-assessed L1 reading abilities. Therefore, the third hypothesis was not confirmed.

Finally, a statistically significant correlation was determined between the L2 reading comprehension test results 
and self-assessed L2 proficiency $(r=0.542, p=0.000)$ as well as with self-assessed L2 reading abilities $(r=0.432$, $\mathrm{p}=0.000$ ). Hence, the fourth hypothesis was confirmed.

The main limitation of the present study is related to the participants since the sample was a convenience one and homogenous with respect to gender, which may have affected the distribution of the obtained results. Moreover, the values for the students' language proficiency and reading abilities are solely based on self-reported data and may have therefore been biased. Hence, it is proposed that future studies apply a random sampling method and a heterogeneous sample as well as combining self-reported data with some more objective measures.

\section{Conclusion}

Preschool and primary school teachers should be proficient readers and therefore should have well-developed reading and reading comprehension skills as well as the abilities necessary to teach them effectively.

The research results presented in this paper show that the participants' reading comprehension is, as expected, better in their mother tongue than in a foreign language. The results further indicate that those participants whose reading comprehension skills were better in one language also had better comprehension skills in the other. Moreover, the results show that the participants who perceived their reading abilities and their language proficiency in L2 to be higher also had better comprehension results. However, an explanation as to why the same results were not obtained for the participants' L1 would require further investigation.

In addition, the analysis related to the use of verbatim phrases from the original suggests that the participants felt safer, especially in their L2, copying phrases from the text-based prompt. This might be interpreted as a subjective (or objective) sense of inadequate language competence, which was expectedly more pronounced in the L2 than in the mother tongue, but it may also refer to insufficiently developed and/or previously acquired ineffective reading or learning strategies. Therefore, we propose that, at all education levels - from elementary to university, and in all languages one is acquiring, it is important to implement the systematic instruction of different approaches, strategies, and specific procedures that contribute to efficient text comprehension.

\section{Conflict of Interest}

The authors declare that they have no conflict of interest.

\section{References}

Alderson, J. C. (2000). Assessing reading. Cambridge, UK: Cambridge University Press.

Benson, M. J. (1991). University ESL reading: A content analysis. English for Specific Purposes, 10, 75-88. https:// doi.org/10.1016/0889-4906(91)90002-E

Bežen, A. (2008). Metodika - znanost o poučavanju nastavnog predmeta [Teaching methodology - A science about teaching a school subject]. Zagreb, Croatia: Učiteljski fakultet Sveučilišta u Zagrebu i Profil.

Braš Roth, M., Markočić Dekanić, A., Markuš, M., \& Gregurović, M.(Eds.) (2010).PISA 2009. Čitalačke kompetencije $z a$ život [Reading competences for life].Zagreb, Croatia: Nacionalni centar za vanjsko vrednovanje obrazovanja. Retrieved from http://www.pisa.hr/knjige/2009-rezultati-sve/Default.html

Brown, A., \& Gullberg, M. (2008). Bi-directional crosslinguistic influence in L1-L2 encoding of manner in speech and gesture. A study of Japanese speakers of English. Studies in Second Language Acquisition, 30, 225-251. https://doi.org/10.1017/S0272263108080327

Burgoyne, K., Whiteley, H. E., \& Hutchinson, J. M. (2011). The development of comprehension and readingrelated skills in children learning English as an additional language and their monolingual, English-speaking peers. British Journal of Educational Psychology, 81, 344-354. https://doi.org/10.1348/000709910X504122

Carrell, P. L. (1983). Some issues in studying the role of schemata, or background knowledge in second language 
comprehension. Reading in a Foreign Language, 1, 81-92.

Carrell, P. L. (1988). Interactive text processing: Implications for ESL/second language reading classrooms. In P. L. Carrell, J. Devine \& D. E. Eskey (Eds.), Interactive approaches to second language reading (pp. 239-259). Cambridge, UK: Cambridge University Press.

Carrell, P. L., Pharis, B. G., \& Liberto, J. C. (1989). Metacognitive strategy training for ESL reading. TESOL Quarterly, 23(4), 647-678. https://doi.org/10.2307/3587536

Celce-Murcia, M., \& Olshtain, E. (2000). Discourse and context in language teaching. Cambridge, UK: Cambridge University Press.

Cook, V. (1992). Evidence for multicompetence. Language Learning, 42, 557-591. https://doi. org/10.1111/j.1467-1770.1992.tb01044.x

Cook, V. (Ed.) (2003). Effects of the second language on the first. Clevedon, UK: Multilingual Matters Ltd.

Čudina-Obradović, M. (2014). Psihologija čitanja: od motivacije do razumijevanja [Psychology of reading: From motivation to understanding: A handbook]. Zagreb, Croatia: Golden marketing-Tehnička knjiga i Učiteljski fakultet Sveučilišta u Zagrebu.

Duffy, G. G. (2009). Explaining reading: A resource for teaching concepts, skills, and strategies (2 ${ }^{\text {nd }}$ ed.). New York, NY: The Guilford Press.

Ferbežar, I., \& Požgaj-Hadži, V. (2008). Kako izraditi jezični test [Designing language tests]. LAHOR, 2(6), 165182.

Gottardo, A., \& Mueller, J. (2009). Are first- and second-language factors related in predicting second-language reading comprehension? A study of Spanish-speaking children acquiring English as a second language from first to second grade. Journal of Educational Psychology, 101, 330-344. https://doi.org/10.1037/a0014320

Grabe, W. (1988). Reassessing the term “interactive”. In P. L. Carrell, J. Devine \& D. E. Eskey (Eds.), Interactive approaches to second language reading (pp. 56-70). Cambridge, UK: Cambridge University Press.

Grabe, W. (2009). Reading in a second language: Moving from theory to practice. Cambridge, UK: Cambridge University Press.

Grabe, W. (2010). Reading in a Second Language. In R. B. Kaplan (Ed.), The Oxford handbook of Applied Linguistics (pp. 88-99). Oxford, UK: Oxford University Press.

Herdina, P., \& Jessner, U. (2002). A dynamic model of multilingualism. Perspectives of change in psycholinguistics. Clevedon, UK: Multilingual Matters.

Huang, J., \& Chen, G. (2019). From reading strategy instruction to student reading achievement: The mediating role of student motivational factors. Psychology in the Schools, 56(5), 724-740. https://doi.org/10.1002/ pits. 22217

Koda, K. (2004). Insights into second language reading: A cross-linguistic approach. Cambridge, UK: Cambridge University Press.

Kolić-Vehovec, S., \& Muranović, E. (2004). Evaluacija treninga recipročnog podučavanja strategija čitanja [Evaluation of reciprocal teaching strategies in reading training]. Suvremena psihologija, 7, 1, 95-108.

Litz, D. R., \& Smith, A. K. (2006). Semantically acceptable scoring procedures (SEMAC) versus exact replacement scoring methods (ERS) for 'cloze' tests: a case study. The Asian EFL Journal Quarterly, 8(1). Retrieved from https://www.asian-efl-journal.com/1133/quarterly-journal/semantically-acceptable-scoring-proceduressemac-versus-exact-replacement-scoring-methods-ers-for-cloze-tests-a-case-study/\#squelch-taas-tabcontent-0-3.

Manguel, A. (1996). A history of reading. London, UK: Harper Collins Publishers.

Mihaljević Djigunović, J. (2006). Interaction between L1 and L2 communicative language competences. Studia Romanica et Anglica Zagrabiensia, 50, 261-277.

Mikulec, A. (2016). Strategije čitanja akademskih tekstova na hrvatskome i engleskome jeziku [Reading strategies used while reading academic texts in Croatian and English language]. (Unpublished doctoral dissertation). Faculty of Humanities and Social Sciences, University of Zagreb, Zagreb, Croatia.

Nagy, W., \& Scott, J. (2000). Vocabulary processes. In M. L. Kamil, P. B. Mosenthal, P. D. Pearson \& R. Barr (Eds.), Handbook of reading research (pp. 343-366). Mahwah, NJ: LEA.

Okkinga, M., van Steensel, R., van Gelderen, A. J. S., van Schooten, E., Sleegers, P. J. C., \& Arends, L.R. (2018). Effectiveness of reading-strategy interventions in whole classrooms: A meta-analysis. Educational Psychology Review, 30(4), 1215-1239. https://doi.org/10.1007/s10648-018-9445-7

Pae, T-I. (2018). A Simultaneous analysis of relations between L1 and L2 skills in reading and writing. Reading Research Quarterly, 54, 109-124. https://doi.org/doi:10.1002/rrq.216

Pavlenko, A., \& Jarvis, S. (2002). Bidirectional transfer. Applied Linguistics, 23, 190-214. https://doi.org/10.1093/ applin/23.2.190 
Pavličević-Franić, D. (2005). Komunikacijom do gramatike [Communication - The path to grammar]. Alfa, Croatia: Zagreb

Pečjak S., Kolić-Vehovec S., Rončević Zubković B., \& Ajdišek, N. (2009). (Meta)kognitivni i motivacijski prediktori razumijevanja teksta adolescenata u Hrvatskoj i Sloveniji [(Meta)Cognitive and motivational predictors of text comprehension among adolescents in Croatia and Slovenia]. Suvremena psihologija, 12, 2, 257-270.

Perkins, K., Brutten, S. R., \& Pohlmann, J. T. (1989). First and second language reading comprehension. RELC Journal, 10(2), 1-9.

Proctor, C. P., August, D., Carlo, M. S., \& Snow, C. (2006). The intriguing role of Spanish language vocabulary knowledge in predicting English reading comprehension. Journal of Educational Psychology, 98, 159-169. https://doi.org/10.1037/0022-0663.98.1.159

Rončević Zubković, B. (2008). Uloga radnog pamćenja i strategijskog procesiranja u razumijevanju pri čitanju kod djece [The role of working memory and strategic processing in children's reading comprehension] (Unpublished doctoral dissertation). Faculty of Humanities and Social Sciences, University of Zagreb, Zagreb, Croatia.

Schwartz, A. I., Mendoza, L., \& Meyer, B. (2017). The impact of text structure reading strategy instruction in a second language: Benefits across languages. The Language Learning Journal, 45(3), 263-281. https://doi.org/ 10.1080/09571736.2013.837092

Shum, K. K.-M., Ho, C. S.-H., Siegel, L. S., \& Au, T. K.-F. (2016). First-language longitudinal predictors of secondlanguage literacy in young L2 learners. Reading Research Quarterly, 51, 323-344. https://doi.org/10.1002/ rrq. 139

Sparks, R., Patton, J., Ganschow, L., \& Humbach, N. (2009). Long-term crosslinguistic transfer of skills from L1 to L2. Language Learning, 59, 203-243. https://doi.org/10.1111/j.1467-9922.2009.00504.x

Sparks, R. L., Patton, J., \& Luebbers, J. (2019). Individual differences in L2 achievement mirror individual differences in L1 skills and L2 aptitude: Crosslinguistic transfer of L1 to L2 skills. Foreign Language Annals, 52(2), 255-283. https://doi.org/10.1111/flan.12390

Spies, T. G., Lara-Alecio, R., Tong, F., Irby, B. J., Garza, T., \& Huerta, M. (2018). The effects of developing English language and literacy on Spanish reading comprehension. The Journal of Educational Research, 111(5), 517529. https://doi.org/10.1080/00220671.2017.1306686

Šamo R. (2011). Naslov?! Koji naslov?! [Title?! What title?!] In I. Vodopija \& D. Smajić (Eds.), Dijete i jezik: Dijete i tekst (pp. 187-202). Osijek, Croatia: Učiteljski fakultet Sveučilišta Josipa Jurja Strossmayera u Osijeku.

Šamo, R. (2014). Čitanjem do spoznaje, spoznajom do čitanja [From reading to cognition, from cognition to reading]. Zagreb, Croatia: Učiteljski fakultet Sveučilišta u Zagrebu.

van Gelderen, A., Schoonen, R., Stoel, R.D., de Glopper, K., \& Hulstijn, J. (2007). Development of adolescent reading comprehension in language 1 and language 2: A longitudinal analysis of constituent components. Journal of Educational Psychology, 99, 477-491. https://doi.org/10.1037/0022-0663.99.3.477

Vasta, R., Haith, M. M., \& Miller, S. A. (1998). Dječja psihologija: Moderna znanost [Child psychology: A modern science]. Jastrebarsko, Croatia: Naklada Slap.

Vaughn, S., Swanson, E. A., Roberts, G., Wanzek, J., Stillman-Spisak, S. J., Solis, M., \& Simmons, D. (2013). Improving reading comprehension and social studies knowledge in middle school Reading Research Quarterly, 48, 77-93. https://doi.org/10.1002/rrq.039

Vijeće Europe, Odjel za suvremene jezike Strasbourg [Council of Europe, Modern Languages Division Strasbourg] (2005). Zajednički europski referentni okvir za jezike [Common European Framework of Reference for Languages]. Zagreb, Croatia: Školska knjiga.

Visinko, K. (2014). Čitanje, poučavanje i učenje [Reading, teaching and learning]. Zagreb, Croatia: Školska knjiga.

Welie, C., Schoonen, R., Kuiken, F, \& van den Bergh, H. (2017). Expository text comprehension in secondary school: For which readers does knowledge of connectives contribute the most? Journal of Research in Reading, 40(1), 42-65. https://doi.org/10.1111/1467-9817.12090

Wu, R.-J. R. (2013). Native and non-native students' interaction with a text-based prompt. Assessing Writing, 18, 202-217. http://dx.doi.org/10.1016/j.asw.2013.01.001

Yamashita, J. (2002). Mutual compensation between L1 reading and L2 language proficiency in L2 reading comprehension. Journal of Research in Reading, 25, 81-95. https://doi.org/10.1111/1467-9817.00160 